\title{
FIRE IN TERRITÓRIO QUILOMBOLA KALUNGA - GO - BRAZIL: AN ASSESSMENT OF FREQUENCY, LOCATION AND CONSEQUENCES
}

\author{
S. A. Santos ${ }^{1 *}$, N. V. Ribeiro ${ }^{1}$ \\ ${ }^{1}$ LAPIG, Laboratório de Processamento de Imagens, Universidade Federal de Goiás, Av. Esperança s/n, Goiânia - GO, Brazil - \\ (saraalves.amb, ribeironoely)@gmail.com
}

KEY WORDS: Fire Frequency, Cerrado, TKG, MCD64, Landsat satellite.

\begin{abstract}
:
The Território Quilombola Kalunga de Goiás (TKG) was established by law nº. 11,409/GO, and was federally regularized as territory in 2009. Its total area covers three Municipalities of Goiás: Monte Alegre de Goiás, Teresina de Goiás and Cavalcante. There live remaining communities of quilombolas. The present work aims to evaluate the recurrence of fires in this Territory and in its surroundings, doing relationships between land use and land cover and burned areas. For this purpose, were used data generated from satellite images, made available in public databases, and procedures in GIS. During the annualized time, the frequency of fires was moderate. Grassland had the largest proportion of burned areas.
\end{abstract}

\section{INTRODUCTION}

Brazil is the country of South America with the highest number of hotspots, and of its 6 biomes, the Cerrado is the one that most suffers with this event. Although this year the Amazon had a large total number of hotspots, the Cerrado is still the Brazilian biome with the largest burned area, totaling 123,111 $\mathrm{km}^{2}$ only this year, an area almost $40,000 \mathrm{~km}^{2}$ higher than last year (INPE, 2019).

According to Hoffmann et al. (2012, p. 639) the greatest flammability of savannas, in relation to forests, can be attributed largely to the presence of grasses, which produce a fuel bed with low bulk density that contributes strongly to faster and more intense fires.

The effect of fire in the Cerrado is dual, includes essential consequences for maintaining some vegetation physiognomy and other threatening, such impacts will depend on the type of vegetation, period of the year in which the burning, beginning or end of the dry period occurs, amount of combustible material, among others.

França et al. (2007, p. 10 and 11) argue that although the fires occurrence and frequency cause a series of adverse impacts, fire is not exogenous to Cerrado, "only those who move away from the normal burning regime cause disturbances and stresses in ecosystems". They add tha: "Fire is an important disturbance in the Cerrado and its recurrence in the last thousands of years has helped establish adapted communities and favour specific characteristics in flora and fauna. It is known that in the cerrados and their associated ecosystems there are both species and communities highly resistant to fire, as well as those sensitive to it, but overall, there is greater resistance than that found in wet forests. The threat of fire is associated with the intrinsic characteristics of the cerrados. The risk of fires during the dry period is determined by climatic conditions, as it hardly rains, and vegetation, which accumulates a lot of dead material, especially herbaceous-subbustive extract. This combination makes the risk of fire in the dry season very high. However, without anthropic action and taking into account the natural conditions of the Cerrado, the fires during this station would be rare, due to the almost absence of lightning, the only natural initiator agent of the fire" (França, H.; Neto, M. B. R.; Setzer, 2007 , p. 10 and 11 ).

The fire effects in the native Cerrado depend particularly of the type of vegetation (Gomes; Miranda; Maria, 2018, p. 282). In many ecosystems the fire frequency determines which species remained or not (FAO, 2006), when there is higher frequency, the most fire-sensitive species cannot "maintain a positive rate of population growth", in the case of the Cerrado, particularly the cerradão species are the most affected (Henriques, 2005, p. 87).

Although the fire tends to "homogenously exclude species from all major plant strains, without excluding, however, whole strains", in the cerrado significant part of its diversity can be maintained, due to adaptations related to fire, even with annual fires (Silva et al., 2011, p. 31-32).

For Rodrigues (2018) the spatial-temporal analysis of burned areas helps in the understanding of patterns related to the fire behavior in relation to the vegetation type. The study of the fire recurrence can be used as the first step for further studies. In this sense, remote sensing is an important tool for the identification and monitoring of burned areas, based on changes in the spectral behavior of the surface after the fires (Resende, 2017 And Pereira et al. 2018).

According to França and Setzer (1999), after the fires the ashes helps the identification of burn scars, even if it remains for a short time, the soil of the affected area remains exposed and in the image will appear different from that covered by vegetation, but if it is an agricultural use area, differentiation will be more difficult.

Therefore, this text aims to evaluate the recurrence of fires in Território Kalunga de Goiás - Brazil and within a radius of 10 $\mathrm{km}$ of its surroundings, using data from burn scars generated from LANDSAT 5, 7 and 8 satellites images and MODIS images (MCD64A1). As well as compare the frequencies of fires between the territory and its surroundings, between

\footnotetext{
* Corresponding author
} 
LANDSAT and MODIS products and associate the recurrence of this event with the vegetation type, use and coverage.

\section{STUDY AREA}

The Território Quilombola Kalunga de Goiás (TKG) is located in the northeastern portion of the Goiás State, and covers three municipalities: Cavalcante, Teresina de Goiás and Monte Alegre de Goiás. The recognition as a historical site and cultural heritage of Goiás State came with the state law 11,409 of 1991, almost 20 years later, with the decree of November 20, 2009 there was the recognition in federal level, as the "Território Quilombola Kalunga ".

Currently the same has an area of $2620.71 \mathrm{~km}^{2}$ demarcated by INCRA in the Goiás State and is subdivided into 5 main subterritories: Vão do Moleque, Vão de Almas e Engenho II, in the municipality of Cavalcante; Ribeirão dos Bois in Teresina de Goiás and Riachão in Monte Alegre de Goiás (Figure 1).

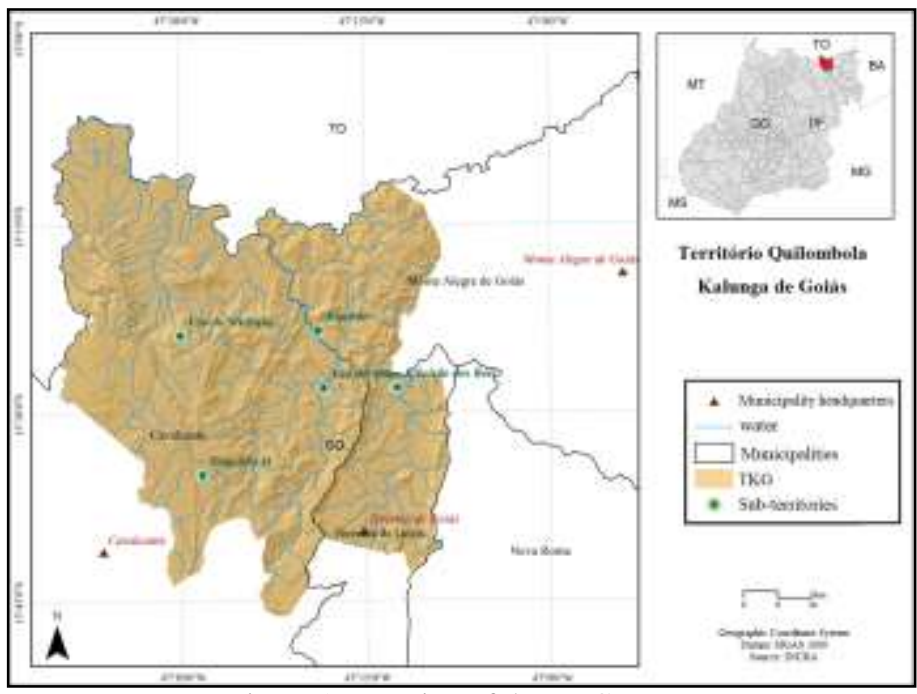

Figure 1. Location of the TKG.

According to Marinho (2017) families residing in the TKG have as one of their main activities the mowing, practicing a subsistence agriculture, cattle raising and collection of cerrado fruit. This standard of living contributed to the permanence of native vegetation and conservation of the site with significant number of "standing cerrado".

In most communities, the houses are with a certain spacing among themselves, with no clusters, with the exception of Engenho II, where was formed a village with several houses nearby. The motivation of this agglomeration was partly the tourism in the region, and today Engenho II has a considerable structure to meet the demands arising from this activity, with the presence of restaurants, inns, camping areas, information boards / advisors, guides, among others.

\section{MATERIAL AND METHODS}

Firstly were acquired burn scars data: MODIS product MCD 64 A1, obtained on the research platform of Lapig Maps; and LANDSAT with a resolution of $30 \mathrm{~m}$ from the INPE database between the period 2007 and 2017.

A $10 \mathrm{~km}$ buffer was made around the TKG. The buffer area corresponds to 297,000 ha, while the TKG 262,000 ha, totaling a study area of 559,000 ha. Such delimitations were used to cut out the burn data.
By procedures in GIS, weight one was attributed to the areas with the presence of burn scars and zero for the without. The data of both sensors were superimposed, which gave rise to 2 fires recurrence maps. It was obtained the frequency of times that certain areas within the territory were burned, going from 0 (areas that did not suffer burned once within the time interval studied) more than 5 times.

Through the use of the 2017 land use and land cover maps of the MapBiomas project, collection 4 published in August 2019, it was possible to intersection these data with those of fires recurrence, which allowed the analysis of which classes of use and coverage corresponded to those with higher frequencies of fires.

\section{RESULTS}

From 2007 to 2017, the total burned area within the TKG vary from $44 \%$ (MODIS product) to $49 \%$ (LANDSAT product) of this, covering areas that burned from 1 to more than 5 times during the time span analysed. In the surroundings the total burned area was lower, $41 \%$ (MODIS product) and 38\% (LANDSAT product).

The figure 2 allows us to observe that areas that have already suffered fires are distributed throughout the Territory, with higher concentration in the western portion of it, and smaller in the north. The two evaluated products present similar distribution of recurrence areas, with some divergent points, mostly originating from the different scales, where LANDSAT products tend to have a higher level of detail and the MODIS a higher generalization of areas.

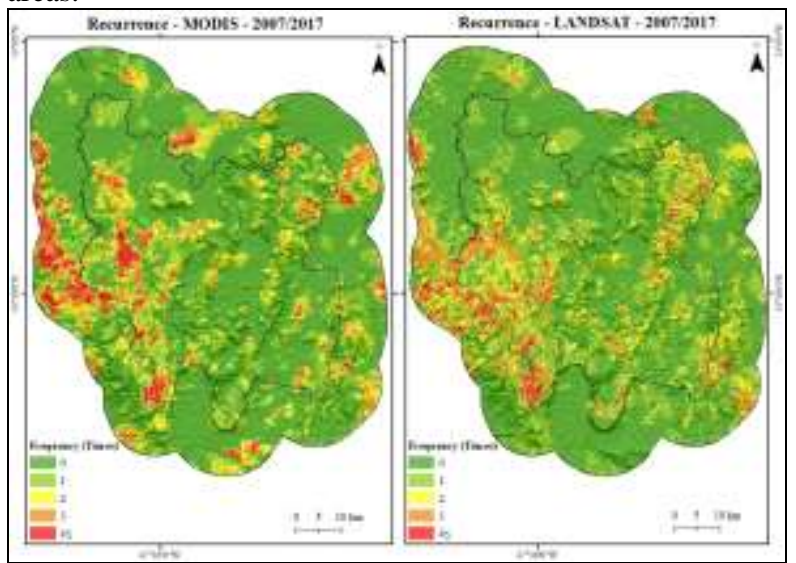

Figure 2. Comparison between MODIS and LANDSAT

recurrences originate from burn scars products.

In the TKG and around them, both products indicate that the areas that burned only once predominate, at the time period evaluated (Figure 3 ). The proportion of areas that burned more than 5 times is the lowest, does not reach $5 \%$ of the study area. In relation to two products evaluated, in the LANDSAT, the areas that burned from 1 to 2 times are slightly larger than in MODIS, while those more than 4 times are more expressive in the latter. In his study Resende (2017, p. 98) identified that the MODIS sensor tends to overestimate burned areas, when compared to other sensors such as LISS-III and OLI, due largely "to the presence of scars of nearby burnings that end up being considered as just a single burn." Despite this overestimation, in the present study, the correlation between the two data, despite the different scales, was favorable, without major differences. 
The recurrence elaborated with the MODIS product indicates that the areas that burned more than 4 times are more representative around the study area, while in LANDSAT, within the TKG there was a higher area with frequency of burn greater than 4 times. Both demonstrate that the surroundings suffered fewer fires than within the Territory.

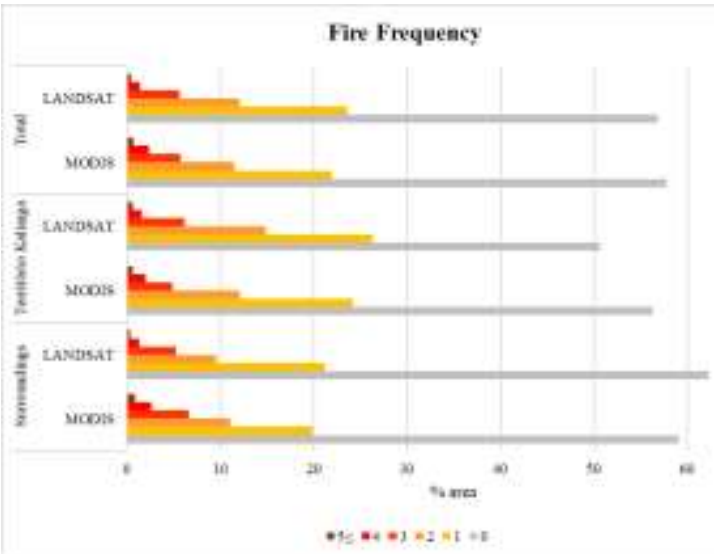

Figure 3. Comparison of the fires frequency, inside and around the TKG, based on MODIS and LANDSAT products.

With the evaluating of coverage and use, it was observed that in both, the TKG and around it, there are three most representative classes, which together represent about $90 \%$ of the total area studied: grassland, forest formation and savanna formation. The grassland corresponds to almost $40 \%$, mainly focuses on the western portion and coinciding with the highest fire frequency areas. Forest formation is the second most representative (27\%), distributed throughout the study area, followed by savanna (24\%), located mainly to the north. The surroundings contains the largest portion of pasture areas, mostly situated in the eastern part, with some bands within the community (Figure 4).

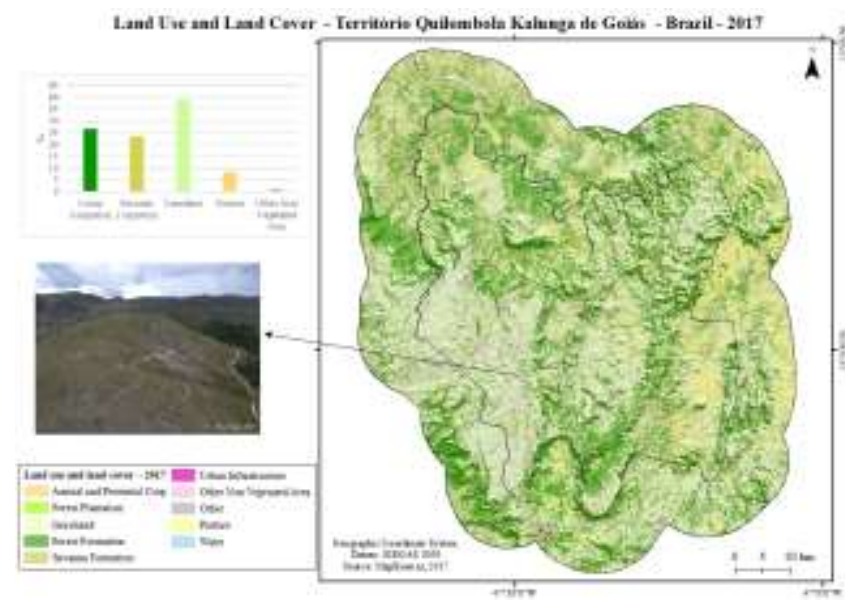

Figure 4. TKG land use and land cover and its surroundings. Figure A: ex. of grassland.

Approximately 57\% (Landsat) to 58\% (MODIS) of the study area corresponds to portions that didn't occur fire events in the last 10 years. The grassland, predominant in the study area, suffered the highest number of fires in the two evaluated products. Regarding the proportion already burned in each class, grassland is also the one with the highest value, from $58 \%$ (Landsat) to 50\% (MODIS). The MODIS product indicates that forest formation had the second largest portion of area ever burned, followed by savanna (Figure 5). LANDSAT, on the other hand, reveals that savanna is the second most burned. The pasture class had the lowest proportion ever burned, between $71 \%$ and $73 \%$ of its area had not yet recorded the occurrence of fire during the time period evaluated.

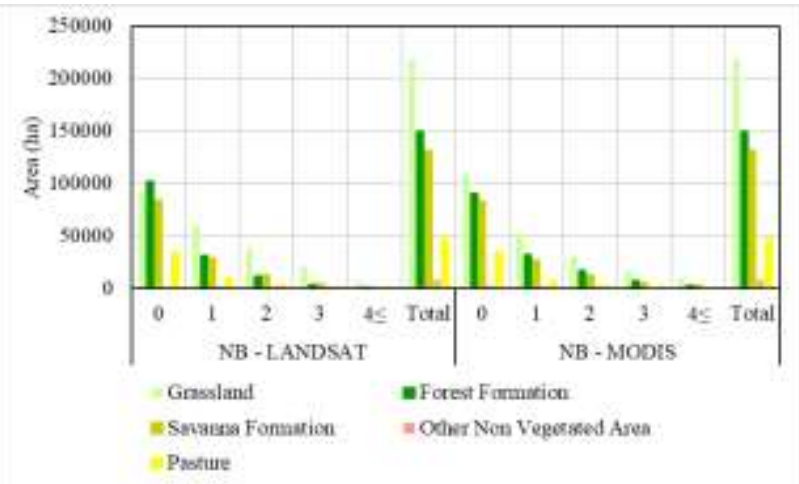

Figure 5. Land use and land cover classes that most burned between 2007 and 2017 at the QKG and its surroundings. NB: Number of times it has suffered burns, according to LANDSAT and MODIS products.

There wasn't observed relationship between environmental physical characteristics or proximity to urban centers with the fire recurrence in the study area, in the last 10 years. On the other hand, the frequency of fires have been strongly related with grassland presence. This raises the question: in the study area, to what extent the type of vegetation influences the fire occurrence and inversely. The type of management practiced by resident populations is an important factor too. These questions reinforce the need for continuous and amplified studies about the fire occurrence in the TKG, since this thematic is not restricted to only one knowledge area, involves questions related to the environment physical characteristics, climatic, social, cultural, and others issues.

\section{CONCLUSION}

The present study identified significant coherence between the two products of burned scars evaluated, MODIS and LANDSAT, with some differences regarding the distribution of scars and overestimated recurrence classes, partly due to different spatial scales. Nevertheless, the two studies were valid for studies related to fires.

The fires recurrence during the period studied in the TKQ and in its surroundings is moderate, the burned and no burned areas are almost in the same proportion. Of those who have already burned, most presented NB 1 and 2. It is interesting to note that within the TKQ there was greater total burned area than in its surroundings.

The grassland is predominant in the study area and the one that suffered the most burns, the NB areas greater than 3 coincide with these areas. Grassland is an open field, rich in grasses, which serve as fuel for fire, and favours the fire occurrence. Therefore, it can be seen that there is a certain relationship in the KQT between the fire recurrence and the vegetation type. The Cerrado is heterogeneous, consisting by a mosaic of vegetation types and uses, with different responses to phenomenon like fire occurrence. The tools and products used in this study are an advance for understanding the behavior of fire in Cerrado. It makes possible evaluations and analysis on a relevant spatial and temporal scale, and open perspectives for other studies and more analyses of this complex phenomenon, the fire in surface. 


\section{REFERENCES}

Fao, 2006. Fire management: Voluntary guidelines - Principles and strategic actions. Rome, FAO.

França, H.; Neto, M. B. R.; Setzer, A., 2007. O Fogo no Parque Nacional das Emas. 2. ed. [s.1.] MMA.

França, H., \& Setzer, A., 1999. A história do fogo no Parque das Emas. Ciência hoje, 26(153), 69-73.

Gomes, L.; Miranda, H. S.; Maria, M., 2018. How can we advance the knowledge on the behavior and and effects of fire in the Cerrado biome? Forest Ecology and Management, 417, 281-290.

Henriques, R. P. B., 2005. Influência da história, solo e fogo na distribuição e dinâmica das fitofisionomias no bioma do Cerrado. Cerrado: Ecologia, Biodiversidade e Conservação (JC Souza Silva \& JM Felfili, eds.). Ministério do Meio Ambiente, Brasília, 73-92.

Hoffmann, W. Et al., 2012. Fuels or microclimate? Understanding the drivers of fire feedbacks at savanna-forest boundaries. Austral Ecology, 37, $634-643$.

INPE. Instituto Nacional de Pesquisas Espaciais. http://queimadas.dgi.inpe.br/queimadas/aq1km/ (01 September 2019).

LAPIG. Laboratório de Processamento de Imagens. Geoprocessamento. Lapig-Maps. http://maps. lapig. iesa. ufg. br/lapig. Html (01 September 2019).

MapBiomas, 2019 http://plataforma.mapbiomas.org/map\#coverage (25 November 2019).

MARINHO, T. A., 2017. Territorialidade e Cultura entre os Kalunga: para além do culturalismo. Caderno CRH, 30, (80), 353-370.

Pereira, I. M. S., 2018. Identification Of Burned Areas By Special Index In A Cerrado Region Of The State Of Tocantins, Brazil. Forest, 48 (4), 553-562.

Resende, F.C., 2017. Análise da Distribuição Espacial das Áreas Queimadas na Porção Nordeste do Bioma Cerrado. [s.1.] Universidade Federal de São João Del-Rei.

Rodrigues, J.A., 2018. Como os produtos globais de área queimada representam os padrões de fogo no Cerrado? Uma avaliação de precisão das coleções MCD64A1. PPGM/IGEO/CCMN/UFRJ (M.Sc.). Rio de Janeiro, 93.

Silva, D. M. et al., 2011. Os efeitos dos regimes de fogo sobre a vegetação de Cerrado no Parque Nacional das Emas, GO: considerações para a conservação da

diversidade. Biodiversidade Brasileira, (2), 26-39. 